\title{
What is Islamism? History and Definition of a Concept
}

\author{
MEHDI MOZAFFARI \\ University of Aarhus
}

\begin{abstract}
Islamism is a complex phenomenon with multiple dimensions and various ramifications. Like other political doctrines, Islamism, in its contemporary shape, is an 'ideology', a 'movement-organisation' and a 'form of government'. This study is predominantly devoted to the analysis of Islamism as a totalitarian ideology. We are interested in knowing how and when this concept has been fabricated; how it has evolved and what differentiates it from 'Islam'. Aiming at a conceptual clarification, we propose a definition of Islamism which enables us to grasp the essence of this phenomenon in its variations (Sunni, Shi' $a$ and Wahhabi) and its different shapes (global and national). Our analysis shows that, despite sectarian and other differences between various Islamist groups, their final objective remains the same. They all aim at the re-instauration of the Islamic might in the world: to achieve this goal, the use of violence is not rejected.
\end{abstract}

\section{Introduction}

Once, Jacques Delors, the former president of the EU Commission, defined the European Union (EU) as a UPO (Unidentified Political Object). By this definition, he of course wanted to emphasise the particularity and the uniqueness of the EU as a new and unprecedented political and economical construction. The UPO metaphor may also be applied to Islamism, as a URO (Unidentified Religious Object), since scholars have not yet reached a consensus about the definition and the meaning of this concept. Since the nineteenth century, the concept 'Islamism' has been used quite differently by western orientalists, islamologists and political scientists. The situation is not much clearer within the Muslim world. Muslims are using various names and appellations to define themselves and their coreligionists, 'Islamiyyûn' [Islamists] being one of them.

It is almost certain that the etiquette of 'Islamism' was used for the first time by French writers at the end of the seventeenth century. Le Petit Robert gives 1697 as the first reference to the word. ${ }^{1}$ The Enlightenment philosopher Voltaire is one of the first writers to use the term: 'this religion is called islamism' ${ }^{2}$ In a work from 1838, Tocqueville found the 'root of islamism in Judaism'. ${ }^{3}$ Caussin de Perceval, Comte de Gobineau, Ernest Renan and Baron Bernard Carra de Vaux equally make use of the term, the latter characterising 'Islamism' as a 'spent religion'.

The above-mentioned writers use 'Islamism' as part of the title of their respective works, either of a book or a chapter. Caussin de Perceval places it in the title of his book Essai sur l'histoire des Arabes avant l'Islamisme, pendant l'époque de Mahomet (3 vols, 1847-9). This title leaves no doubt that, in the mind of the author, 
'Islamism' means 'Islam', e.g. the religion founded by Muhammad. Comte de Gobineau has devoted Chapter II of his book on Religions et philosophies dans l'Asie Centrale to the study of l'Islamisme persan. He considers Islamism as a camouflaged mixture of religions prior to Islam. After this very short remark, Gobineau continues his fascinating analysis on Iranian and central Asian societies, although he does not concern himself to engage in a further analysis of 'Islamism'. It is very clear that Gobineau uses the term 'Islamism' only in the sense of 'Islam' without any specific political or ideological connation. Some years later, Ernest Renan, a compatriot of Gobineau, used the term 'Islamism', especially at the famous conference he held at the Sorbonne (Paris) on 29 March 1883. This conference became very famous, and still is, because of its highly polemical aspect. At that time, an enigmatic Muslim personage named Sayyid Jamal alAfghani (1838-97) was agitating in Egypt, Persia and the Ottoman Turkey. He sojourned in Paris and engaged himself in a lively debate concerning the position of Islam towards modernity and science. It is in this context that Renan holds his speech on Islamisme et la Science. Renan, in perfect accordance with the intellectual context of his epoch, uses 'Islamism' as a parallel to 'Christianism' (the equivalent of 'Christianity' in English). By 'Islamism', Renan simply means 'Islam' as he uses 'Islam' and 'Islamism' as interchangeable terms.

'Islam' and 'Islamic' have become the most frequently used terms by western islamologists, orientalists and political scientists. This replacement is very clear indeed among a huge number of western writers of multiple disciplines, from Ignaz Goldziher (1850-1921), Arnold Toynbee (1852-83), Max Weber (1864-1920), Oswald Spengler (1880-1936), Fernand Braudel (1902-85), Claude Cahen (19091991), Ann K.S. Lambton (b. 1912), Henri Laoust (d. 1976) and William Montgomery Watt (1909-2006) to contemporary scholars such as Samuel Huntington and Francis Fukuyama. We do not find the word 'Islamism' in the index of their works. Prior to the Islamist revolution in Iran in 1978-79, the terms 'Islamism' and 'Islamists' are also practically absent from the vocabulary of newspaper reporters.

The change in the vocabulary happened with the outbreak of the Islamic revolution under the leadership of Ayatollah Khomeini, who preached a political Islam and established the first 'Islamist government' in the twentieth century. This religious revolution made it imperative to find a new vocabulary in order to outline the specificity of this new phenomenon. Suddenly, the world witnessed a multitude of terms and formal rules destined to grasp the 'novelty' of the new era in the history of Islam. By way of example, frequently used terms were 'Islamic fundamentalism', 'radical Islam', 'Islamic revival' and 'political Islam'. These terms, which became titles of numerous books and multiple articles, were clear and ambivalent at the same time. They indicated that this kind of 'Islam' is quite different from other versions of 'Islam'. However, what precisely does this 'new' form of 'Islam' contain? The ambiguity remains almost complete. Surely, it has become evident that this particular form of Islam was (more) political, often violent and severely critical towards the West, and, last but not least, determined in its hostility towards established regimes in the Muslim world. Nevertheless, this list determining the main characteristics of 'Islamic fundamentalism', 'political Islam', 'Islamic radicalism' or 'radical Islamism' does not bring about a clear conceptualisation of the phenomenon.

We had to wait until the tragic events of 9/11 to witness the rise of the need for conceptual clarification. It is a fact that, since $9 / 11$, the use of the word 'Islamism' has increased among politicians and journalists worldwide. It is equally 
observable that scholars have progressively focused their attention on the ideological contients of Islamism.

Diverging from the nineteenth-century definition, 'Islamism' is no longer an emulation of 'christianisme', but a rather new and independent concept. This change is observable in scholars' works, and particularly so in books and articles posterior to 9/11. For example, two eminent French islamologists, Olivier Roy and Gilles Kepel, previously used both 'political Islam' and 'fundamentalist Islam' extensively whereas they now tend to use 'Islamism' more and more often. The term appears neither alone nor besides 'neofundamentalism' or 'political Islam'. Actually, the latter term is not equivalent to 'Islamism' in Olivier Roy's terminology. 'Political Islam' designates a failed project in his works, whereas 'Islamism' denominates the new form of activist Islam. ${ }^{4}$ Bruno Etienne, director of the Observatoire du Religieux at the Department of Political Science, University of Aix-en-Provence, has dedicated much of his time to the study of Islam and gives the following definition of 'radical Islamism': 'it proposes as a cure of all the evils of modernity/modernisation the return to political Islam's roots: the ideal City State of the Rashîdun, (the 'rightly guided' four Caliphs: 632-61)'. ${ }^{5}$

In general, 'Islamism' is abundantly present in many other articles and books. Malise Ruthven's new book on Fundamentalism is another example. Despite the title, she extensively uses 'Islamism' in her analysis. Parallel to 'Islamism', some authors are also using 'radical Islamism' (William E. Shepard), 'Islamic Activism' (Quintan Wiktorowicz) or 'Mobilizing Islam' (Carrie R. Wickham). ${ }^{6}$ The above examples are only representative, tracing the general trend on this issue without being exhaustive.

How do Muslim authors designate themselves and their coreligionists? In Arabic, Muslim/Muslims are called Muslìm (singular masculine), Muslima (singular feminine), Muslimûn (plural masculin) or Muslimât (plural feminine). However, the Muslim equivalent to Islamists is Islamiyyûn; it is used only in this form (plural masculine) and therefore with a significantly limited and restricted use. The Qur'an uses the terms Muslimûn along with $M u^{\prime}$ minûn [Believers], never Islamiyyûn. Islamic classical works generally respect the Qur'anic terminology. Theologians from the four prevailing schools (Hanafi, Mâliki, Shâfi'i and Hanbali) use Muslimûn and Muslim, not Islamiyyûn. The same can be noticed in the works of great medieval historians, jurists and thinkers such as Ibn Ishâq (d. 768), Ibn Hishâm (753-5), Bukhari (810-70), Farâbi (870-950), Mas'udi (d. 958), Mawardi (972-1058), Avicena (980-1037), Ghazâli (1058-1111), Averroes (1126-98) and Ibn Khaldun (1332-1406). The same tradition is observed and followed in modern times among Muslim authors of the eighteenth, nineteenth and twentieth centuries. This trend is observed with authors such as Muhammad Ibn Abd al-Wahhab (1703-92, the founder of Wahhabi sect), Sayyid Jamal al-Afghani (1838-97), Muhammad Abduh (1849-1905) and Rashid Rida (1865-1935). Continuing our route forward, we observe that Muslim leaders who played a crucial role in the twentieth century did not use 'Islamism' in their abundant works. Hasan alBanna (1906-48), in his famous work Rasâ'̂̂l [Tracts], extensively uses 'Muslims' and 'Muslim Brothers' especially when addressing his own disciples. When he investigated 'Islam', he sporadically used the term 'Islam al-shâmil' [Self-sustained Islam] or 'Islam al-Hanif' [the True Islam]. Neither the zealous ideologue of the Muslim Brotherhood Sayyid Qutb (1906-66) nor Mawdudi (1903-79), an eminent Islamist leader of Southwest Asia, used the term 'Islamism'. A last example would be Ayatollah Khomeini (1902-89), who brought political Islam from theory 
into reality. While being a Shi'a, he used the same terms as the Sunnis, e.g. 'Muslimîn' or 'Musalmanân' (Persian version of Muslims).

However, a number of Muslim authors actually have used 'Islamism' [Islamiyyûn]. The Sudanese Hasan al-Turabi (b. 1932) is one of them. When he discusses different fractions among Muslims in his book Al-Islam wal Hukm [Islam and Government], he uses Islamiyyûn to designate 'political Muslims for whom Islam is the solution, Islam is religion and government and Islam is the Constitution and the law'. ${ }^{7}$ Some (Muslim) lay authors increasingly use Islamiyyûn, as for example the Tunisian Salwa al-Sharafi, author of Al-Islamiyyûn wal-Dimuqrâtiyya [Islamists and Democracy]. ${ }^{8}$ We find a thorough analysis of Islamism in Larbi Sadiki's book The Search for Arab Democracy, where he presents a critical analysis on Islamist discourse and ideas, although not as an independent study, but as an appendix to the main issue of his book (democracy). The problem is that Sadiki, like western authors, deals with the terms 'Islamism' and 'Islamists' without providing a clear definition of these concepts. ${ }^{9}$

Aziz al-Azmeh, the author of Islams and Modernities, labels contemporary Islamic movements 'political Islamism' and not, for instance, 'Islamic fundamentalism'. ${ }^{10}$ William Shepard uses 'Islamic totalism' to describe 'the tendency to view Islam not merely as a "religion" in the narrow sense of theological belief, private prayer and ritual worship, but also as a total way of life with guidance for political, economic, and social behaviour'. Commonly, this takes the form of the claim that Muslims should have an 'Islamic state', 'that is, a state in which all law is based on the Shari' $a^{\prime}$. This is, in our view, a fairly precise definition of what 'Islamism' is. However, it is difficult to understand why Shepard constructs a neologism 'Islamic totalism' different from 'Islamism', which in his view is 'the tendency to view Islam as an ideology'. ${ }^{11}$ Unfortunately, he does not elaborate further on the reason for this distinction between the two terms 'Islamic totalism' and 'Islamism'. Shepard's merits lie essentially in his conscious academic démarche, where he acknowledges the necessity of defining concepts that a scholar has the intention to use in his/her works. He points out that labels such as 'fundamentalist', 'modernist' and 'secularist' have 'undoubtedly often functioned as obstacles to understanding the actual people and tendencies involved, in part because they are frequently used without explicit definition' ${ }^{12}$

It is equally interesting to observe how various Muslim groups address each other, whether in a friendly or an unfriendly manner. Let us mention some of the most noticeable and politically significant groups. At the very beginning of Islam's history, the first group which was distinguished in a negative way from the community of Muslims is the Munafiqun [Hypocrites]. At the time of Muhammad's rule in Medina, they expressed views that differed from and even contradicted Muhammad's world vision. They built a mosque without his authorisation, which led him to qualify their mosque as Masjid al-Zirar [The Mosque of Dissension]. The Qur'an is particularly severe vis-à-vis this particular group. The second group is the Khawârij, who, under the Caliphate of Ali (656-61), disapproved of his decision to accept the arbitration between him and his rival Mu'awiya. Later in history, the immense Muslim empire has witnessed the emergence of a variety of concurrent groups and sects: Sunni (various schools) vs Shi'a (different sects), Mujâhid [Combatant] vs Munâfiq [Hypocrite], Khâriji, ['Excommunicated'], Mu'tazili ['Rationalists'], Usûli [Theological Fundamentalist] vs Akhbâri [believing that the tradition of the prophet provides sufficient guidance], and finally, in the Iranian context, Khodi [Insider] vs Nâ khodi 
[Outsider]. In fact, Iranian 'Islamists' of our day call themselves 'Usul gara', which literally means 'fundamentalist', but in a positive sense. It designates a 'person of principles' who is the 'true Muslim'. These Muslim authorities who are against Islamists often call them Irhâbiyyûn [Terrorists] or Mutatarrifûn [Extremists].

In the light of these considerations, it seems necessary to present a definition of 'Islamism'. This definition must satisfy two demands. First, it must encompass all or at least the most significant elements that are normally attributed to 'Islamism'. Second, it must exclude attributes that are alien to 'Islamism'.

\section{Definition of Islamism}

Having all these interrogations in mind, we propose a definition as follows:

'Islamism' is a religious ideology with a holistic interpretation of Islam whose final aim is the conquest of the world by all means.

This definition is composed of four interrelated elements. The first is a religious ideology, the second a holistic interpretation of Islam, the third conquest of the world, and finally the fourth and the last element is the use of all means in the search for the final objective. Each of these four elements will be briefly examined in the following.

\section{Islamism is a religious ideology}

Among western thinkers and scholars, there has been a tendency to attribute a kind of religious aureole to non-religious ideologies. In The Social Contract (Chapter 8, Book 4), Jean-Jacques Rousseau calls what he regarded as the moral and spiritual foundation essential for any modern society 'civil religion'. To some authors, contemporary political ideologies such as communism, fascism and Nazism are considered as 'political religion'. ${ }^{13}$

Compared with the above-mentioned, Islamism has a particularity: it is already a religious phenomenon, and labels like 'civil', 'secular' or 'political' religions do not apply to it. 'Clerical fascism' is perhaps the nearest concept which comes closest to Islamism. ${ }^{14}$

The concept of 'Islamism' is composed of two elements: 'Islam' and 'ism'. The former stands for a religion and a civilisation with its specific history, and the latter indicates a non-Islamic suffix. The composition of these two elements refers to a bi-pillar construction, composed by religion and ideology.

Islam is a religion with a long history and with different theological and juridical schools. The Qur'an is not really a coherent book able to provide Muslims with clear and unambiguous guidelines. Roughly speaking, it is divided into two very different and somewhat contradictory sets of statements, principles and commandments. The surats [chapters] are divided into the Mecca period of 12 years' length (from 610 to 622), and the Medina period of ten years' length (from 622 to 632). The first and initial period is characterised by relative moderation, toleration and pluralism. You find this aspect of Islam in some verses in the Qur'an. For example the Qur'an states: 'You shall have your religion and I shall have my religion' (surat 109, verse 6).

We may call the Mecca period the moderate phase of Islam. In contrast, the Medina period is essentially characterised by politics, power and war. The 
moderate and open-minded language and behaviour give place to a power language. The following verse shows the change in the Qur'an's language when it states:

And slay them wherever ye find them, and drive them out of the places whence they drove you out, for persecution is worse than slaughter. And fight not with them at the Inviolable Place of Worship until they first attack you there, but if they attack you (there) then slay them. Such is the reward of disbelievers (s. 2, v. 191).

This example is an illustration of the Qur'an's ambiguous discourse and its ambivalence in recommended behaviour. The Medina period can be termed as the radical phase of Islam. The Qur'an also reflects this part of Islam. The fact is that some Muslims (known as 'cultural Muslims') refer to the Mecca period alone, and others (Islamists in particular) consider the Medina period as the achievement of Islam in its final shape. Then there is a third group (the overwhelming majority of Muslims) which refers to both periods. This consideration among many others demonstrates that it is practically impossible to identify the 'real message' of Islam. Therefore, the world is facing various manifestations of Islam at a time when no consensus exists among Muslims on fundamental aspects of their faith, except for two cardinal, and thus very general points: the acceptance of the unity of God (Allah), and the reliability of the prophecy of Muhammad as the last Prophet.

This means that if we take only the Qur'an, which is the main source of Islam and which should be the point of convergence between Muslims, it leads us to further confusion about Islam. If we add to the Qur'an other sources of Islamic creed as for example Sunna, Hadith, Rivaya, Fatwas and so on, we get more than one billion disoriented and confused persons, all Muslims of divergent articles of faith, all convinced that their own version and their own understanding of Islam represent the only truth. Yet, while 'Islam' is a general, elusive and ambiguous phenomenon, 'Islamism' as an ideology represents a coherent, specific and identifiable construction.

Ideology may be defined as: 'sets of ideas by which men explain and justify the ends and means of organised social action, with the aim of preserving or reconstructing a given reality'. ${ }^{15}$ In totalitarian systems ideologies are a powerful instrument for the mobilisation of the masses as well as sources of legitimacy, sources of the sense of mission of a leader or a ruling group. ${ }^{16}$ In this sense, Islamism is more than merely a 'religion' in the narrow sense of theological belief, private prayer and ritual worship, but also serves as a total way of life with guidance for political, economic and social behaviour. ${ }^{17}$ Selectively, Islamists pick up some elements in Islam and turn them into an ideological precept. Islamism indeed fulfils all requirements of an ideology, but it goes beyond the purely ideological dimension and sacralises the very essence of ideology. Therefore, Islamism differs on this point from other totalitarian ideologies as it takes its legitimacy from a double source: ideology and religion. Owing to its double character, actions undertaken by Islamists are seen by them as religious duties. Where a Nazi feels responsible to his Führer, an Islamist is responsible to his Leader and before Allah.

Islamism is also a regressive ideology which is oriented towards the past (salaf). Its ideal is the Medina model under Prophet Muhammad as well as the caliphate of the first four caliphs (Khulafâ al-Râshidûn). In this respect, Sayyid Qutb is 
explicit when he declares: 'If Islam is again to play the role of the leader of mankind, then it is necessary that the Muslim community be restored to its original form' ${ }^{18}$

\section{The holistic interpretation of Islam}

In the above discussion, we said that Islamists are selective when choosing religious principles from the original sources of Islam. How can a set of selective elements be holistic? There is no contradiction here. In the first place, Islamists argue that their set of selected elements is, in reality, the 'true' Islam and, in the second place, they are convinced that this 'true' Islam' is holistic and embraces all aspects of Muslims' life in eternity. The holism is based on the absolute indivisibility of the trinity Dîn [Religion], Dunya [Way of life] and Dawla [Government]. This indivisibility is supposed to be permanent and eternal. Its ultimate goal boils down to the fulfillment of this mentioned triad on a global scale. The triad's totalitarian character is confirmed by the writings of the main contemporary Islamist thinkers and leaders: Hasan al-Banna and Sayyid Qutb of Egypt, Ayatollah Khomeini of Iran and Abu Alâ Mawdudi of Pakistan (see infra: 'global Islamism').

\section{Conquest of the world}

To Islamists, the existing world is both wrong and repressive. It is wrong because the existing world does not correspond to Islamic principles. Islam as a political power is no longer as predominant as it used to be in the past. The world is also considered repressive because non-Muslims occupy what the Islamists consider to be Muslim territory (e.g. Palestine, Kashmir, Chechnya) or because Muslims live under severe repression from their own (anti-Islamic) governments.

In order to get rid of these conditions of repression and wrong-doing, the Islamists mainly propose two other 'ideal reference points'. The first is the 'Medina model', e.g. society as it was shaped by Muhammad himself. The second is the classical era of the Caliphate. The Caliphate is one of the longest political institutions in history. Its lifespan extended from the year 632, right after the death of Muhammad the Prophet, until its abolition by Mustafa Kemal in the year 1924. During this very long period of time, the Caliphate experiences were of course not all of the same nature, and not all the experiences were triumphant. The Caliphate was sometimes unified, strong and glorious, whereas at other times it was divided, in conflict, in crisis and weak. The first type of experiences was of incomparably shorter duration than the second. The second reservation concerns the non-Sunni Muslims, especially the Shi'a communities. According to the general position of Shi'a, the Imamate, not the Caliphate, is the rightful and legitimate institution. However, Shi'a Islamists like Ayatollah Khomeini, without hiding their preference for the Imamate, have moved slowly but consistently towards a more consensual attitude. Together with the Sunni Islamists, they share pride in, but also nostalgia for the disappeared past. Therefore, it is fair to say that the restoration of the Caliphate today represents a general claim of all Islamists, independently of their sectarian membership.

To the Islamists, the restoration of the Caliphate is the first step towards the 'Islamisation' of the world. From their perspective, Islam constitutes a universal religion whose aim is to rule over the entire world. After all, Allah promised the regency on the earth to His 'virtuous servants', as claimed in the Qur'an: 
the earth is Allah's, to give as a heritage to such of His servants as He please; and the end is (best) for the righteous. He said: 'It may be that your Lord will destroy your enemy and make you inheritors in the earth; that so He may try you by your deeds' (s.VII, v. 128-9).

Utopia? Perhaps. But a powerful one, capable of inspiring action and motivating people to sacrifice their lives.

\section{By all means}

The Islamists' spectrum of means to reach the above mentioned goal is quite wide, expanding from propagation, peaceful indoctrination and political struggle to violent methods such as assassination, hostage taking, terrorist and suicide actions, and even massacre of civil populations. However, the use of violence is not systematic. All Islamists do not use violence all the time, but some have recourse to it sometimes and, since there are various Islamist groups of different obedience and with different affiliations and histories, the use of violence by Islamists remains non-concomitant. It is possible that, simultaneously, some Islamists use extremely violent methods in one part of the world while other Islamists use non-violent methods in another part. This variation in patterns of action is determined by different factors. It can be the consequence of a strategic and deliberate choice by the leadership, as is the case for al-Qaeda. It can also be the result of prudential considerations when a group of Islamists living in a particular situation prefer to follow a relatively quietist and hence pacifistic line for a while. This line of action was for example adopted by the Muslim Brotherhood in Jordan, and for certain periods of time in Egypt. In Europe, Hizb al-Tahrir al-Islami [the Islamic Liberation Party] is a good example of an Islamist movement which for the time being claims to be non-violent. The quietist attitude of some Islamists is an exception. In general, the use of violence is integral to their strategy for achieving their ends. Among the various violent methods, terror is proven to be the preferred one, and is indeed frequently used by Islamist groups. The use of terrorism by Islamists confirms a general rule that Hannah Arendt formulated in her study of totalitarianism: 'Total terrorism (is) the essence of totalitarian government ... guiding principles and criteria of action are, according to Montesquieu, honor in monarchy, virtue in a republic and fear in a tyranny'. ${ }^{19}$ Terrorism, and diffusion of fear in the civil population, is therefore the instrument of choice in the hands of Islamist groups.

\section{Islamism: a divided movement}

Islamism is a monist entity, but is far from being a monolithic movement. 'Despite the global aspirations of their ideologues, Islamists have no centre; there is no overall pan-Islamic radical leadership' ${ }^{20}$ On this particular point, Islamism is similar to communism and fascism. Communism was divided between various tendencies which were sometimes antagonistic (Stalinism, Trotskyism, Maoism, Albanian and North Korean versions). There were also different variations within the fascism movements. For example, fascism in Italy was not identical with the Action Française or Falangism. Islamism is characterised by the same kinds of divisions; different sub-groups within the global movement promote divergent interpretations of the ideological creed. For the sake of clarity, it is convenient to 
summarize the division inside the universe of Islamism around two axial pillars: division determined by sub-religious affiliations, and division emanating from the diverse scope of claims and ambitions.

\section{Sunni, Shi' $a$ and Wahhabi}

In the domain of sub-religious affiliations, Islamism is divided into three main branches: Sunni, Shi'a and Wahhabi. This classification is neither perfect nor exhaustive, but it is useful. For instance, Wahhabi is also a Sunni sub-sect, but it is so different from other Sunni sub-sects that it may be treated as an autonomous entity. Sunnism is divided into four theological and juridical schools: Hanafi, Mâleki, Shâfi'i and Hanbali. Wahhabi is a derivative of the Hanbali School with a particularly dogmatic interpretation of Islam.

The Sunni Islamists represent the vast majority of Islamists. Sunni movements embrace the geographical space reaching from Mali to Bali, from the Somalian desert to the Pakistani Himalayas. Chronologically, Sunni Islamism is older than both Shi'a and Wahhabi Islamism. Its origins may be traced back to Ibn Hanbal (780-855), then to the theologian al-Ghazali (1058-1111). ${ }^{21}$ Contemporary Islamism as a movement and as an organisation is a phenomenon of the twentieth century. It emerged with the creation of the Muslim Brotherhood by Hasan al Banna in Egypt in 1928. The Muslim Brotherhood is a mother association for suborganisations such as Tanzim al-Jihad [Jihad Organisation] or Al- Takfir val-Hijra [Atonement and Emigration], the latter being responsible for the assassination of the president Anwar el-Sadat in 1981. People like Ayman al-Zawahiri (second to Usama Bin Laden) come from this type of organisation.

The Wahhabi branch of Islamism is found essentially in Saudi Arabia, to a lesser degree in different Emirates of the Persian Gulf, and finally in some parts of Caucasus (Chechnya in particular) and central Asia. The Wahhabi Islamism is rooted in the instructions of Muhammad 'Abd al-Wahhab' (1703-92), who was deeply influenced by Ibn Taymiyya (1268-1328), a Hanbali theologian of the Middle Ages. Compared with other Muslim sects, Wahhabis are generally known to be particularly intransigent and at times even violent. Unprecedented global and spectacular terrorist actions like the 9/11 operation have become a trademark of Wahhabi Islamism. It exercises brutality within Muslim societies too, as seen in the case of the assassination and beheading of hostages in Iraq, committed by al-Zarqawi's brigades. At the present time, frontiers between the Wahhabi and the non-Wahhabi are blurred, and sectarian differences have pratically disappeared. For example, al-Qaeda counts in its ranks a number of Sunni Muslims of different sectarian or theological orientation. Leading al-Qaeda personalities such as al-Zarqawi (killed in Iraq, 7 June 2006) and especially Ayman al-Zawahiri are Sunni, but not Wahhabi Muslims. Such a fact attests to the trans-sectarian character of this organisation, which is developing into an ecumenical global terrorist organisation.

Shi'a Islamism is represented mainly by the post-revolutionary Iran, a country where about $80 \%$ of the population is affiliated to Shi'a Islam. Following the Islamic revolution of 1979, Iran became an active centre of terrorist activities in the name of Islam. The initial event was the hostage affair of 4 November 1979, where 52 American diplomats and staff of the US embassy in Tehran were kept prisoners for 444 days. The Shi'a Islamist group Hezbollah from Lebanon was created under the auspice of the Islamic Republic of Iran in 1982 as a reaction 
against the Israeli occupation of South Lebanon. For years, the organisation committed violent actions against military and civilian persons in Israel, in the name of legitimate defence against the invader. ${ }^{22}$ In 2005 part of the organisation took part in the parliamentary elections in Lebanon by winning 14 seats in a parliament of 128 seats.

Historically, relations between Sunni and Shi'a have generally been conflictual, and the intensity of conflict has varied depending on political contexts. As an example, in recent times, Sunni-Shi'a relations have particularly deteriorated in Iraq and in Pakistan, resulting in sporadic mutual assassination and the burning of the other confession's mosques. Relations between the Wahhabi and the Shi'a have been even more critical and predominantly hostile. According to the Wahhabi traditional teaching, the Shi'a is a heretical sect and as such it is not recognised as Muslim. Owing to a range of crucial events such as the victory of the Islamist revolution in Iran in 1979, the assassination of the Egyptian president Anwar el-Sadat in 1981, the success of the Mujahidin in Afghanistan, when they pushed the Red Army out of country (in 1989), the rise of the Taliban, then of alQaeda, relations between the Sunni, the Shi'a and even the Wahhabi Islamists have seen a noticable amelioration. Shâfi'i Muslims like the Egyptian Zawahiri concluded an alliance with the Wahhabi Bin Laden; and the Iranian Shi'a Islamist regime supported Sunni groups like the Hamas in Palestine and the Algerian Islamist group (Front Islamique du Salut/FIS). Furthermore, there has been no sign of hostility between the al-Qaeda or other jihadist Wahhabi groups and the Islamist Shi'a, neither with the Iranian government nor the Hezbollah in Lebanon. It is also a fact that, despite Ayatollah Khomeini's vehement criticism of the Saudi dynasty in the 1980s, the Iranian post-Khomeini government maintains very good relations with the Saudi government. On the Wahhabi side, Usama Bin Laden, following almost the same path, avoids appealing to sectarian feelings in his discourse.

The hostility between Shi'a and Wahhabi Islamists only surfaced after the Coalition Forces' invasion of Iraq in 2003. The Iraqi section of al-Qaeda, under the then leadership of the Jordanian al-Zarqawi, began an open and bloody war against the Iraqi Shi'a. In one of his taped declarations (14 September 2005), Zarqawi pronounced on behalf of the al-Qaeda organisation in the Land of Two Rivers [Iraq], and declared 'all-out war on the Rafidha [a pejorative term for Shi'a], wherever they are in Iraq'. Nevertheless, he exempted militant groups around Muqtada Sadr (an extremist Shi'a militant organisation) from being targets. In the same vein, it is interesting to mention a letter of Zawahiri (second to Bin Laden) to Zarqawi (the al-Qaeda commander in Iraq). In this letter, released by the Americans on 13 October 2005, Zawahiri criticised attacks on the Shi'a in friendly albeit vigorous terms and called Zarqawi to reason and moderation. In the light of the ongoing events in Iraq (September 2006), it seems that Zawahiri's advice is being ignored by both the Sunni Islamists and other Sunni resurgents. The Lebanon crisis of July-August 2006 provides another interesting case for examination of Sunni-Shi'a Islamist relations. Roughly speaking, the Iranian Shi'a regime and the Alawi (a sub-sect of the Shi'a) Syrian government sided with the Hezbollah of Lebanon. Sunni and Wahhabi governments (e.g. Saudi Arabia and Egypt) chose a more balanced attitude, criticising implicitly the action of Hezbollah - kidnapping of two Israeli solders on the Israeli territory - while supporting the Lebanese government, while the Sunni Islamists have so far remained silent. 
To sum up, it is no exaggeration to say that, despite some important differences and even reciprocal animosity among Sunni, Shi'a and Wahhabi Islamists, they have more in common than in opposition. They believe in the totalitarian character of Islam, and they strive towards the same ultimate goal (a global Umma). Moreover, they cultivate strong anti-western feelings as well as the use of violent methods of actions. They share the same ideals, practice the same methods and nourish the same patterns of solidarity and animosity towards the external world. All these elements point to the existence of a tacit strategic alliance of these three Islamist sectarian branches.

\section{National and global Islamism}

The second criterion for differentiating one Islamist group or organisation from another is the scope of its goal. This criterion leads us to identify two categories of Islamists: the 'National Islamists' and the 'Global Islamists'. Both groups share the same ideology; but the scope of their goal is not the same.

National Islamism embraces movements whose claims are partly articulated by the modern concept of nation, especially in four geographical areas, Kashmir, Palestine, Lebanon and Chechnya. The geopolitical context of each area brings about different uses of nationalism by these Islamist groups. Lashkar-e-Tayyiba [The Pure Army] ${ }^{23}$ wants Kashmir to be separated from India and integrated into Pakistan. The purpose of the Islamic Regiments who fight in Chechnya is to separate Chechnya from Russia in order for it to become an independent state. Hamas claims independence for Palestine, but also insists on the obliteration of an already existing nation, Israel. Hezbollah, while supporting the idea of obliterating Israel, for the time being concentrates on extending its political and military domination within an already existing state: Lebanon.

What adds to the dynamic nature of the Islamist nationalist groups is that they very often evolve following a centrifugal or a centripetal scheme. A centrifugal force expands from a centre, whereas a centripetal force attracts other forces towards its centre. The Palestinian Hamas is unique because of its strong emphasis on the centripetal aspect. Following the Hamas covenant, Palestine is the navel of the globe', as it is the homeland of central Muslim holy sites, like the alAqsa Mosque in Jerusalem, and was the first Muslim territorial conquest outside the Arabian Peninsula. Therefore, following the Mithâq [Covenant], every Muslim in the world has the duty to fight for the elimination of Israel and the restoration of Palestine as a Muslim country [Filastin al-Muslima]. ${ }^{24}$ Hamas repeatedly demands military, social, educational and financial support from the other Islamic nations, openly inviting fighters from outside to present themselves in Palestine. Where more secular Palestinian movements like the Palestine Liberation Organization (PLO) and al-Fatah tend to present the conflict as being between Israelis and Palestinians, Hamas formulates it as an Islamic struggle against world Zionism. Article Six of the Hamas Charter stipulates that:

The Islamic Resistance Movement is a distinguished Palestinian movement, whose allegiance is to Allah, and whose way of life is Islam. It strives to raise the banner of Allah over every inch of Palestine' (article 6). Hamas explicitly defines its nationalism 'part of the religious creed. Nothing in nationalism is more significant or deeper than in the case where an enemy should tread Muslim land' (article 12). 
The Covenant identifies World Zionism as Islam's enemy number one, and argues that this enemy uses Palestine as its basis for the destruction of the surrounding Muslim countries, and finally the conquest of the world. Therefore, Muslims have to converge their efforts on Palestine. Hamas does not explicitly advocate centrifugal expansion and world domination by Islam, but the nostalgia of the Caliphate is present as a background reference in the movement's Covenant. It should not be forgotten that Hamas is originally a branch of the Egyptian Muslim Brotherhood Association, to which the restoration of the Caliphate represents a necessity. ${ }^{25}$

A neighbour to Hamas, the Shi'a-movement Hezbollah, has also occasionally invited foreign fighters to join the movement, but it is not at all a dominant feature of the movement's ideology as it is for Hamas. While being largely financed and supported by Iran, it insists on its authentic Lebanese character.

Although most of Hezbollah's operational activities are limited to the Lebanese and North Israeli area, its objectives include not only centrifugal expansion of the Shi'a-dominated territories within the Lebanese borders, but also ultimately the obliteration of the State of Israel and the elimination of western influence in the Middle East. ${ }^{26}$ Hezbollah explicitly states that it does not aim at fighting on a global level. This being said, the global dimension is still present, but as a very marginal and non-violent statement in a Hezbollah statement from 1998 where it calls for people all over the world to follow its Shi'a-muslim creed:

We understand Islam as a message that aims at establishing justice, security, peace and rights for all people no matter what nation, race or religion they belong to (Hezbollah Press Office, 20 March 1998).

The Kashmiri Wahabbi-inspired group Lashkar-e-Tayyiba (or Taiba) is an excellent example of a nationalist Islamist movement with a strongly centrifugal ideology. It concentrates most of its terrorist actions in one location, Kashmir, while cultivating a mindset that prepares for a global extension of its operational activities. In order to pursue this extension, the movement is developing linkages with other terrorist groups in various places, such as the Philippines, Nepal, Afghanistan, Palestine, Chechnya, Kosovo and Eritrea. ${ }^{27}$ To the Lashkar-e-Tayyiba, ${ }^{28}$ Kashmir's $^{\prime}$ projected merger with Pakistan is only the first step towards the re-establishment of Islamic rule over India. This step should be followed by the conquest of all other parts of the world that have been under a Muslim ruler at some stage in history, from Myanmar to Spain. The ultimate goal is to realise a global 'pure Islamic caliphate' that would reign even on the American continent. As Lashkar-e Tayyiba is affiliated with Usama Bin Laden's International Islamic Front for Jihad against the USA and Israel as well as with the United Jihad Council, it integrates both levels of the above-mentioned paradigm of 'nationalism' and 'globalism'.

Global Islamism embraces movements such as the Muslim Brotherhood in its various forms, Khomeinist movements in Iran, followers of Mawdudi in Pakistan and elsewhere, and of course the organisation al-Qaeda. They all pursue the same goal, although at different paces and through different discourses. This goal is, in brief, the restoration of Islam's might and glory, to be achieved once all Muslim territories have been liberated from the yoke of non-Muslim occupants. The consistency and cumulative character of the discourse of global Islamists can be traced in the writings of the most influential leaders of this doctrine. The selection which follows is not exhaustive, though quite representative. It should be stressed 
that none of these leaders have ever pronounced a discourse which would indicate their opposition to the re-instauration of the Islamic empire and the conquest of the world by Islam. On the contrary, the same kind of discourse has been repeated by the same leaders in different occasions.

Hasan al-Banna is the first who pronounced his programme for reaching this goal. He said:

If Islam is again to play the role of the leader of mankind, then it is necessary that the Muslim community be restored to its original form. It is necessary to revive that Muslim community which is buried under the debris of the man-made traditions of several generations, and which is crushed under the weight of those false laws and customs which are not even remotely related to the Islamic teachings, and which, in spite of all this, calls itself the 'world of Islam' (Introduction) - Rasâ'îl. ${ }^{29}$

Sayyid Qutb is the second Islamist thinker and leader who has explicitly formulated the use of jihad for reaching the ultimate goal: the conquest of the world. In powerful terms, Qutb writes:

Those who say that Islamic Jihad was merely for the defence of the 'homeland of Islam' diminish the greatness of the Islamic way of life and consider it less important than their 'homeland'. This is not the Islamic point of view, and their view is a creation of the modern age and is completely alien to Islamic consciousness. ... Of course, in that case the defence of the 'homeland of Islam' is the defence of the Islamic beliefs, the Islamic way of life, and the Islamic community. However, its defence is not the ultimate objective of the Islamic movement of Jihad, but is a means of establishing the Divine authority within it so that it becomes the headquarters for the movement of Islam, which is then to be carried throughout the earth to the whole of mankind, as the object of this religion is all humanity and its sphere of action is the whole earth. ${ }^{30}$

The Pakistani theologian Mawdudi explains in his work Islam Today how success can be obtained by following Muhammad's example. In the chapter 'The real cause of success', Mawdudi outlines how the first Muslims were a 'small but devoted group of courageous and selfless people', who succeeded in creating a city state in which the Islamic principles 'no longer remained mere theoretical expressions, they became a living reality in individual and social life'. The Medina model is the 'Ideal period', as Mawdudi titles one of his chapters. ${ }^{31}$ From this model, Mawdudi explains how Islam is spread throughout the world with means including the use of violence. To Mawdudi, the experience of Muhammad and his immediate successors must serve as a model for Muslims today.

Despite the fact that Ayatollah Khomeini represents the Shi'a minority, which has been the victim of the Sunni caliphate throughout history, he is convinced of the necessity of worldwide Islamic power. He said:

This is a duty that all Muslims must fulfill, in every one of the Muslim countries, in order to achieve the triumphant political revolution of Islam. We see, too, that together, the imperialists and the tyrannical self-seeking rulers have divided the Islamic homeland. They have separated the 
various segments of the Islamic umma from each other and artificially created separate nations.

In order to assure the unity of the Islamic umma, in order to liberate the Islamic homeland from occupation and penetration by the imperialists and their puppet governments, it is imperative that we establish a government. ... The formation of such a government will serve to preserve the disciplined unity of the Muslims (Islamic Government). ${ }^{32}$

Last but not least, one of the most important letters of Zawahiri (second leader of al-Qaeda after Bin Laden) to Zarqawi (former al-Qaeda's commander in Iraq, killed on 8 June 2006) very clearly expresses the author's intentions concerning the future of the world. This letter, which was intercepted by the Americans on 13 October 2005, states: 'It has always been my belief that the victory of Islam will never take place until a Muslim state is established in the manner of the Prophet in the heart of the Islamic world, specifically in the Levant, Egypt.' To realise this plan, Zawahiri outlines a four-stage plan, as follows:

First, expel American forces from Iraq. Second, establish a caliphate over as much of Iraq as possible. Third, extend the jihad to secular neighboring countries, with specific reference to Egypt and the Levant - a term that describes Syria and Lebanon. And finally, war against Israel.

In this statement, Bin Laden's deputy frames the broad plans for the al-Qaeda movement. Moreover, in a book smuggled out of Afghanistan in December 2001, Zawahiri said that the goal of jihad is to establish a religious state throughout the Islamic world and 'reinstate its fallen caliphate and regain its lost glory'.33

\section{Concluding remarks}

In the present study we have limited our investigation to tracing the evolution of Islamism as a concept through history. Then, we tried to highlight the constituent elements of Islamism, which introduced a broader discussion about the very definition of Islamism itself. We have demonstrated that the concept of 'Islamism' has been transformed throughout the nineteenth and twentieth centuries from designating a religion (Islam) to defining a particular ideology which is rooted in Islam. Labelling the groups of Muslims who make an ideological interpretation of Islam with the purpose of justifying their militarism has not been an easy task. Contemporary western authors have used different names reaching from 'fundamentalism' and 'extremism' to 'radical Islam' and 'Jihadism'. Broadly speaking, Muslim authors have followed a similar pattern, as they have begun to use the term 'Islamism' only recently, probably inspired by western writings. The new tendency within both the Muslim and the western worlds - points towards a consensus around the term of Islamism. This new 'Islamism' is very different from what the classical western authors had in mind. The new Islamism is understood as an equivalent to totalitarian ideologies like Nazism and communism. Thus, as a new concept, Islamism needs to be defined to avoid ambiguity. We have proposed a new definition which embraces important characteristics of Islamism as a phenomenon.

The rest of the study was devoted to identifying different types of Islamist groupings, in terms of their sectarian characteristics and according to their 
national or global goal. In this respect, we came to the conclusion that, despite sectarian and other differences among various Islamist groups, their final objective remains the same. They all aim at the re-instauration of the Islamic might in the world: to achieve this goal, the use of violence is not rejected, or is explicitly advocated.

However, the expression of this same goal does find some variation among Islamists. In general, leaders and thinkers of the Muslim brotherhood, such as Hasan al-Banna and Sayyid Qutb, as well as some post-Qutbian leaders of the 1980s, e.g. Shukri Mustafa, ${ }^{34}$ are explicit about the global issue. Islamists such as Khomeini and even Mawdudi have, in practice, been more preoccupied with the establishment of an Islamic government in their respective home-countries, Pakistan and Iran. Nonetheless, the idea of establishing an Islamic world government and a world Umma is present in their discourse and action, although, in a less elaborate theoretical form than in the case of al-Banna and Qutb.

\section{Notes}

1. Le Petit Robert, Dictionnaire de la langue française, CD-ROM edn (Paris: Dictionnaires Le Robert/ VUEF, 2001-3).

2. Martin Kramer, "Coming to Terms: Fundamentalists or Islamists", Middle East Quarterly 10/2 (Spring 2003), pp.65-77. Also available at: http://www.martinkramer.org/ (accessed 19 September 2006).

3. Alexis de Tocqueville, Oeuvres complètes, vol. 3, J.P. Mayer (ed.) (Paris: Gallimard, 1961-77), p.155.

4. Olivier Roy, Globalised Islam: The Search for a new Ummah (London: Hurst \& Company, 2002); Gilles Kepel, Jihad: The Trial of Political Islam (London: I.B. Tauris, 2004); Gilles Kepel, The War for Muslim Mind: Islam and the West (Cambridge, MA: Harvard University Press, 2004).

5. Bruno Etienne, L'Islamisme radical (Paris: Hachette, 1987).

6. William E. Shepard, "Islam and Ideology: Towards a Typology", International Journal of Middle East 19/3 (August 1987), pp.307-35; Carrie R. Wickham, Mobilizing Islam (New York: Columbia University Press, 2002); Quintan Wiktorowicz (ed.), Islamic Activism (Bloomington, IN: Indiana University Press, 2004).

7. Hasan Al-Turabi, AI-Islam wal-Hukm (London: Al-Saqi, 2003), p.49.

8. Salwi al-Sharfi, Al-Islâmiyyûn wal-Dimuqrâtiyya (Tunis: Manshurât Alâmât, 2001).

9. Larbi Sadiki, The Search for Arab Democracy (New York: Columbia University Press, 2004).

10. Aziz al-Azmeh, Islams and Modernities (London: Verso, 1993).

11. Shepard, "Islam and Ideology", p.308; Wickham, Mobilizing Islam, pp.307-8.

12. Shepard, "Islam and Ideology".

13. Juan J. Linz observes that 'there is no generally accepted definition of political religion' and adds "what is distinctive about political religion in my view is that the elaboration of the "religious" manifestations is initiated in the political sphere, and that it is inner-worldy rather than making reference to transcendental realities like a god or gods and prophets of that god' (p.108). See Juan J. Linz, "The Religious use of Politics and/or the Political use of Religion", in Hans Maier (ed.), Totalitarianism and Political Religions (London: Routledge, 2004), pp.107-8.

14. 'Clerical fascism' is an ideological construct that combines the political and economic doctrines of fascism with theology or religious tradition. The term has been used to describe organisations and movements that combine religious elements with fascism, support by religious organisations for fascism, or fascist regimes in which clergy play a leading role. The term clerical fascism emerged in the 1920s to refer to the links between the Church and Italian fascism. More recently, the term has been used by scholars, such as Hugh Trevor-Roper, who seek to create a typology of fascism, distinguishing between clerical fascism and more radical types of fascism such as Nazism. See H.R. Trevor-Roper, "The Phenomenon of Fascism", in S. Woolf (ed.), Fascism in Europe (London: Methuen, 1981), especially p.26, quoted in Roger Eatwell, available at: http://staff.bath.ac.uk/mlsre/ ReflectionsonFascismandReligion.htm (accessed 19 September 2006). Raymond Aron prefers the term 'religion séculière' rather than 'civil' or 'political' religion. See Raymond Aron, L'opium des intellectuels (Paris: Calmann-Lévy, 1968), pp.361-67. According to Emilio Gentile, fascism was the first and prime instance of a modern political religion that affirmed the primacy of faith, brought 
mythical thought into power, consecrated the figure of the charismatic leader as the interpreter of the national consciousness and prescribed an obligatory code of ethical commandments for the citizens and instituted a collective political liturgy. See Emilio Gentille, "The secularisation of Politics: Definitions, Interpretations and Reflections on the Question of Secular Religion and Totalitarianis", Totalitarian Movements and Political Religions, $1 / 1$ (Summer 2000), p.40; see also his book: Politics as Religion, translated by George Staunton (Princeton, NJ: Princeton University Press, 2006).

15. Zeen Sternhell, "Fascist Ideology", in Walter Laqueur (ed.), Fascism: A Reader's Guide (London: Penguin Books, 1982), p.329.

16. Juan J. Linz, Totalitarian and Authoritarian Regimes (Boulder: Lynn Rienner 2000), p.77.

17. Shepard, "Islam and Ideology", p.308.

18. Saayid Qutb, Ma'âlim fi al-Tariq [Milestones], (1964), Chapter 4, available at: http:/ /www.youngmuslims.ca/online_library/books/milestones/Introduction.asp (accessed 19 September 2006).

19. Hannah Arendt, The Origins of Totalitarianism (New York: Harvest Books, 1966), pp.466-7.

20. Michael Whine, "Islamism and Totalitarianism: Similarities and Differences", Totalitarian Movements and Political Religions 2/2 (Autumn 2001), p.60.

21. Abu Hâmid, Muhammad al-Ghazali was a Shâfi'i theologian who began a 'crusade' against the discipline of philosophy/falsafah and against philosophers/falâsifah. His book: Tahafut al-Falâsifah [The Incoherence of Philosophers], which was translated by mediaeval Latin translators as Destructio Philosophorum, is considered to be the first vigorous tentative to replace the Greek philosophy with Islamic theology (Kalâm). His nostalgic and regressive tendencies predominate in his colossal work: Vivification of Islamic Theology [Ihyâ al-' $\hat{u} l \hat{u} m$ al-Dîn]. As a counter reaction to Ghazali's anti-Hellenic philosophy, Averroes (Ibn Rushd, d. 1198) wrote his famous book: The Incoherence of the Incoherence [Tahâfut al-Tahâfut]. To Islamists, Ghazali stands as a defender of the purity and self-sufficiency of Islam as well as a true salafi to whom the Muslim salvation is conditioned by a return to the original period of Islam. See (among others): Henri Laoust, $L a$ Politique de Gazâli (Paris: Paul Geuthner, 1970) and Ibn Rushd's, Tahafut al-Tahafut, translated by Simon Van Den Berght (London: The Trustees of the 'E. J. W. Gibb Memorial', 1978).

22. The US government accuses Hezbollah of being responsible for the April 1983 bombing of the US Embassy in Beirut that killed 63 persons; also of being behind the 1983 Beirut barracks bombing, a suicide truck bombing that killed 241 US marines in their barracks in Beirut in October 1983 and a range of other terrorist actions. See Amir Taheri Holy Terror: The Inside Story of Islamic Terrorism (London: Hutchinson, 1987), pp.123-9; Wazzah Shararah, Dawlat Hezbollah [Hizbollah's Government] - (Beirut: dâr al-Nahar, 1996), pp.280-2.

23. In Kashmiri, the Arabic word 'tayyiba' becomes 'toiba'.

24. Andrea Nüsse, Muslim Palestine: The Ideology of Hamas (Amsterdam: Harwood Academic, 1998).

25. Ziad Abu-Amr, Islamic Fundamentalism in the West Bank and Gaza (Bloomington, IN: Indiana University Press, 1994).

26. In an open letter to the 'Downtrodden in Lebanon and in the World' (16 February 1985), Hezbollah pronounced very clearly its main goals in Lebanon, the Middle East and even in the world. The key word in the letter is the elimination of Israel. See 'Appendix B' in Augustus Richard Norton, Amal and the Shi'a: Struggle for the Soul of Lebanon (Austin, TX: University of Texas Press, 1987), pp.167-87.

27. K. Santhanam, Sreedhar, Sudhir Saxena and Manish, Jihadis in Jammu and Kashmir: A Portrait Gallery (New Delhi: Sage Publications, 2003), p.229. See also: http://www.satp.org/satporgtp/ countries/india/states/jandk/terrorist_outfits/lashkar_e_toiba.htm (Indian source) (accessed 19 September 2006).

28. See Hassan Abbas, Pakistan's Drift into Extremism (New York: Armonk/London: M.E. Sharpe, 2005), p.211-16.

29. Hasan Al-Banna, Rasâ'il [Five Tracts of Hasan Al-Banna], translated by Charles Wendel (Berkeley, CA: University of California, 1978).

30. Saayid Qutb, Ma'âlim fi al-Tariq [Milestones], (1964), Chapter 4, available at: http:/ /www.youngmuslims.ca/online_library/books/milestones/Introduction.asp (accessed 19 September 2006).

31. Abul 'Ala al-Mawdudi, Islam Today, available at: http://www.witness-pioneer.org/vil/Books/ M_IT/default.htm (accessed 19 September 2006).

32. Rouhollah Khomeini, Hukumat-e Islami (in Persian) [Islamic Government] (Najaf: Clandestine, 1971), pp.41-2. A better version of the Islamic Government under the title Velayat-e faqeeh is published by The Institute of Compilation and Publication of Imam Khomeini's works, Tehran, undated, available at http://www.iranchamber.com/history/rkhomeini/ayatollah_khomeini. php, p.24 (accessed 19 September 2006). 
33. Ayman al Zawahiri, quoted by Marc Sageman in the posting "Statement of Marc Sageman to the National Commission on Terrorist Attacks Upon the United States July 9, 2003", http:// www.globalsecurity.org/security/library/congress/9-11_commission/030709-sageman.htm (accessed 19 September 2006).

34. Shukri Mustafa (1942-78) was a prominent figure of the group Jama'at al-Muslimûn (Muslim Group or Community) in Egypt which is commonly known as al-Takfir w'al Hijra [Atonement and Emigration]. According to Shukri's group, the Jama'at was in a phase of weakness analogous to that experienced by the prophet Muhammad in Mecca. The group had to build its strength is isolation which necessitated migration (hijra) away from the corrupting influence of a 'deviant' society. See Sadik J. Al-Azm, "Islamic Fundamentalism Reconsidered: A Critical Outline of Problems, Ideas and Approaches", South Asia Bulletin, Part II, 14/1 (1994), pp.11-20. 
Copyright of Totalitarian Movements \& Political Religions is the property of Routledge and its content may not be copied or emailed to multiple sites or posted to a listserv without the copyright holder's express written permission. However, users may print, download, or email articles for individual use. 